\title{
ZEOLITE-BEARING AMYGDALOIDAL VOLCANIC AND VOLCANOCLASTIC ROCKS AT GABAL KATHERINE AREA, SOUTHERN SINAI, EGYPT
}

\author{
Imbarak, S. Hassan ${ }^{1,2}$ and Ahmad, R. Al-Rashed ${ }^{1}$ \\ 1- Science Department, College of Basic Education, Public Authority for Applied Education and \\ Training, Adailiya 73251, Kuwait (ahmedbufarsan@gmail.com).
}

2- Department of Geology, Faculty of Science, Suez Canal University, 41522, Ismailia, Egypt. (imbarak25@gmail.com).

\begin{abstract}
The Gabal (G) Katherina complex in the southern Sinai of Egypt (Being a part of the ArabianShield) consisting mainly of volcanic arc granitoids, epiclastics and pyroclastic volcanic rocks (Rutiq volcanics), followed latterly by the emplacement of high-level intrusions (Katherina ring dyke) and calc-alkaline to slightly alkaline granites. The later-phase intrusions into the country rocks produced deferent degrees of contact aureole with significant alteration effects especially on the early-formed intermediate pyroclastics with their amygdules lava flows producing different degrees of zeolitization in the pyroclastic rocks, were investigated using Optical Microscopy, Scanning Electron Microscopy (SEM), X-ray diffraction (XRD) and wet chemical analyses. The studied volcanic rocks fall considerably in the basaltic andesite and rhyodacite- dacite fields and show subcalc-alkaline to calcalkaline affinities. On the other hand, the amygdaloidal volcanic rocks show low-temperature hydrothermal alteration characterized by the abundance of chloritization. Geochemically; Hf, Ta, Sr, Y, and $\mathrm{Nb}$ show slightly enrichment relative to the other zeolite-rich samples suggesting partial releasing of immobile elements from the volcanic rock during the alteration processes. Furthermore, zeolites found to fill the cavities in a non-uniform behavior. The subclass minerals such as phillipsite and chabazite have been accompanied by palagonite clasts, smectite, and calcite. Zeolites also occur in fibrous aggregates, partly or completely filling spheroid, ellipsoidal or irregular amygdules.
\end{abstract}

Keywords: Zeolite-zeolitization, Volcanic rocks; Geochemistry; St. Katherine- Sinai- Egypt.

\section{INTRODUCTION}

The zeolite mineral group includes hydrated aluminum silicates of alkali and alkali earth elements, with open-framework structures of linked ( $\mathrm{Si}, \mathrm{Al}) \mathrm{O}_{4}$ tetrahedra (Passaglia and Sheppard, 2001; Deer et. al., 2004). They are well known for their properties as ion exchangers and as ,molecular sieves (Hay, 1978; Frankart and Herbillon, 1970; El-Nahal and Whiting, 1973; Mumpton, 1977; Southard and Kolesar, 1978; Hawkins, 1984; and Dyer, 1988). Zeolites commonly form well-developed crystals in veins, cavities and vugs of volcanic rocks, or exist as fine-grained crystals homogeneously distributed in the matrix of volcanoclastic or sedimentary rocks. Regardless of the formation mechanism, the zeolite deposits are characterized as "sedimentary deposits".

Volcanic glass (silicic, alkali, mafic) is the most common parent material of zeolite minerals. Smectite, feldspars, feldspathoids and biogenic silica may also act as precursors in the formation of zeolite minerals. With increasing temperature, certain zeolites, such as the alkaline zeolites clinoptilolite or mordenite, may become unstable and may also act as precursors of stable zeolite species, such as analcime.

In the last 60 years, zeolite minerals have been recognized as major constituents of altered volcanoclastic rocks in various geological environments, such as burial metamorphic environments, saline-alkaline lake, marine and freshwater environments (Mumpton, 1977; Southard and Kolesar, 1978) and geothermal environments. 


\section{Imbarak, S. H. and Al-Rashed, A. R.}

Hassen and Al-Rashed (2017) studied the mineralogical and morphological characteristics of soils derived from volcanic rocks of W. Al-Saq, Gabal Katherine area. The soil morphology was described as a brownish-red colored, blocky structure with high to moderate development, clay films and clay loam to clay texture Based on the preservation of primary pyroxene grains, the soil particles had experienced only slight chemical weathering. Hassen and Al-Rashed (op cit), recorded amygdaloidal volcanic debris, filled with zeolite minerals.

\section{GEOLOGICAL FRAMEWORK}

St. Katherine Complex is situated in a high mountainous area of southern Sinai between $33^{\circ} 57^{\mathrm{ce}}$ to $34^{\circ} 00 \mathrm{~S}$, and $28^{\circ} 26$ to $28^{\circ} 34 \mathrm{E}$. The Katherina Ring Complex geological mapping was carried out by authors (E.g.: Eyal and Hezkiyahu, 1980; El Morsy, 1988; El Masry, 1991; Abdel Maksoud et al., 1993; Hassan, 1997 and Eyal, 2014).

The area is composed mainly of epiclastic, volcanic, and granitoid rocks of the Precambrian Arabian-Nubian Shield. Later emplaced high-level intrusions of the Catherina ring dyke porphyries and the calc- alkaline to slightly alkaline granites of the Catherina pluton intrude into a country-rock made up mainly of metamorphic rocks, diorites, older granitoids, and inter-bedded epiclastic and volcanic rocks (Fig. 1).

Fig.1: Geological map of the Katharina area, Sinai, Egypt after Eyal and Hezkiyahu 1980).

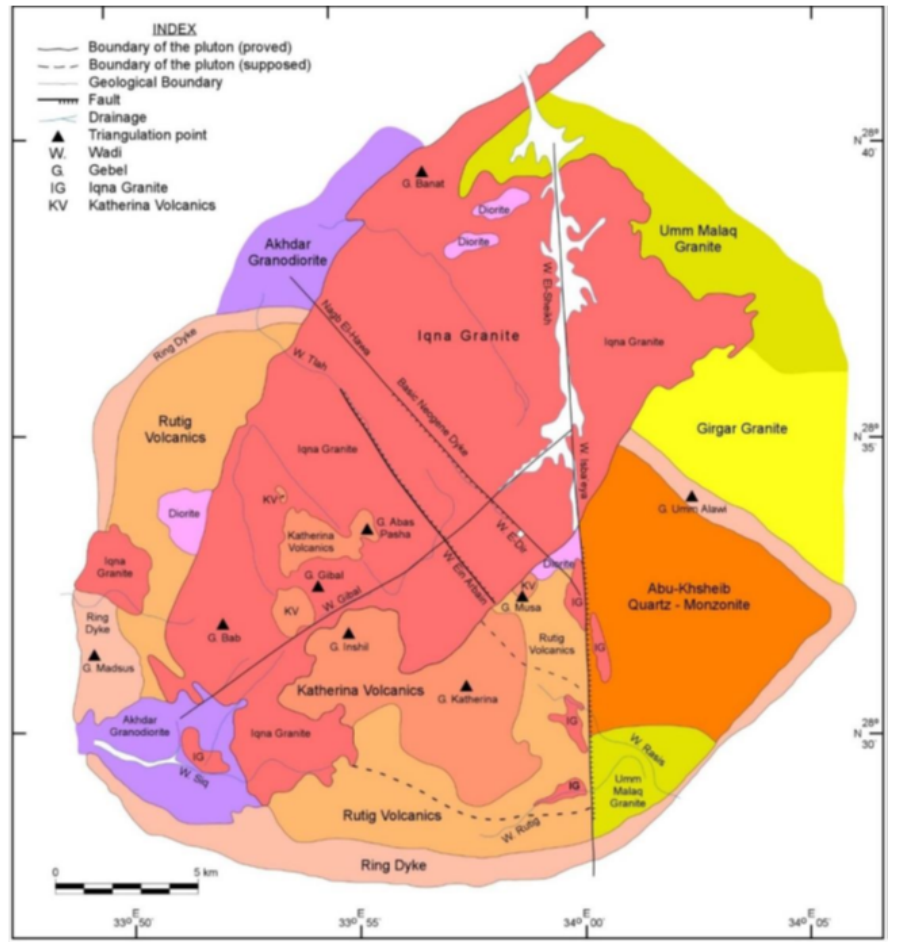

The Rutig volcano-sedimentary succession occupies an irregular discontinuous crescent-shaped outcrop, exposed to the south and east of G. Katherina and extending from G. Musa in the east to Wadi (W) Rutig and W. Tala'at Ghofra in the south, covering an area of about $60 \mathrm{~km}^{2}$ (Fig. 2 and 3 a and $b$ ).

Three main stages for the formation of the complex are recognized: (1) The volcanic stage (Katherina volcanic), (2) The subvolcanic stage comprises peralkaline porphyritic microgranite intrusions, the porphyritic quartz- monzonite intrusion, two ring dikes of complex composition, and scattered perthite quartz syenite dikes, (3) The Katherina alkaline granite pluton was emplaced at the final stage of the KRC formation (Eyal et al. 2014). The Rutig Formation (Eyal and Hezkiyaku, 1980; El-Masry et al., 1992; Eyal et al., 1994) constitutes a thick volcano-sedimentary sequence that crops out in the south and west of the area enclosed by the Ring Dike. 
Zeolite-bearing amygdaloidal volcanic and volcanoclastic rocks

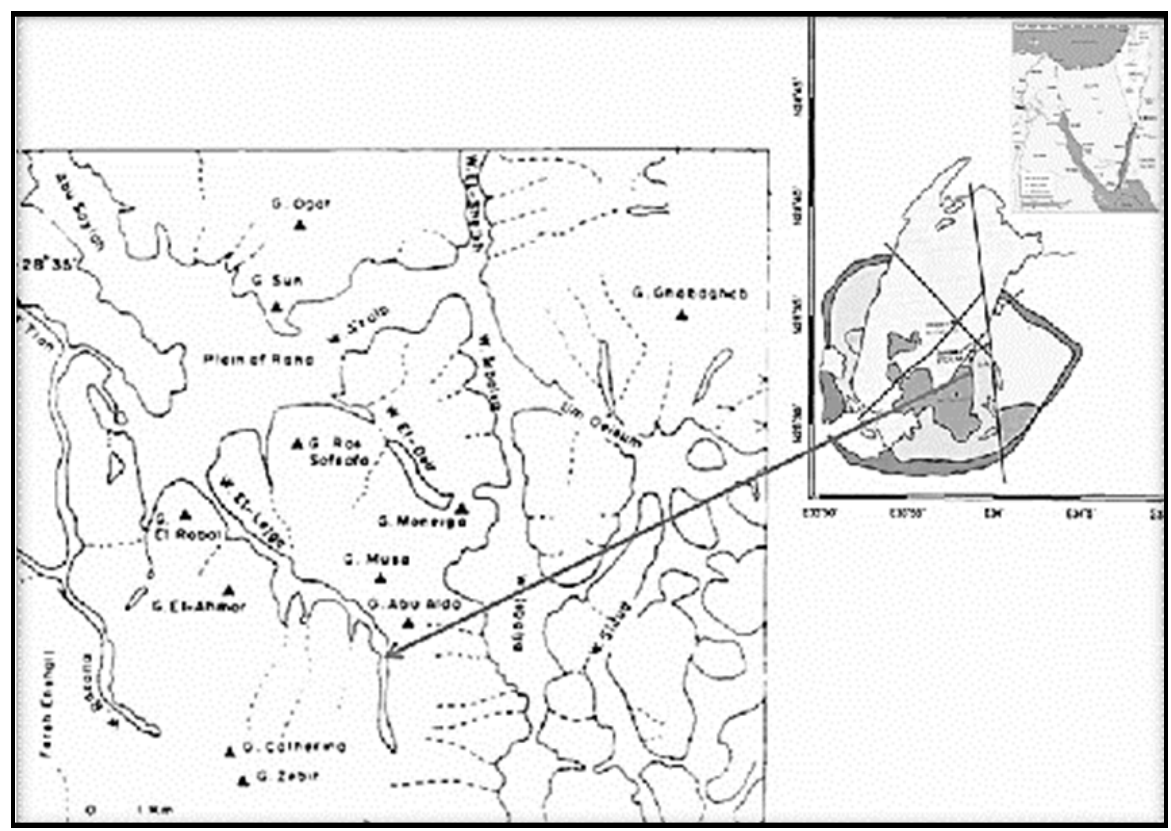

Fig. 2: Topographic map showing the location of the study area.

The Rutig succession ( $>2000 \mathrm{~m}$ thick) comprises intermediate to acid lava flows and pyroclastic rocks alternating with epiclastic volcanic rocks consisting of conglomerates and sandstones (Eyal and Hezkiyahu, 1980 and El-Masry, 1991). El- Masry et al. (1992) concluded that the associated epiclastic, pyroclastic and lava flows were erupted under subaerial conditions.

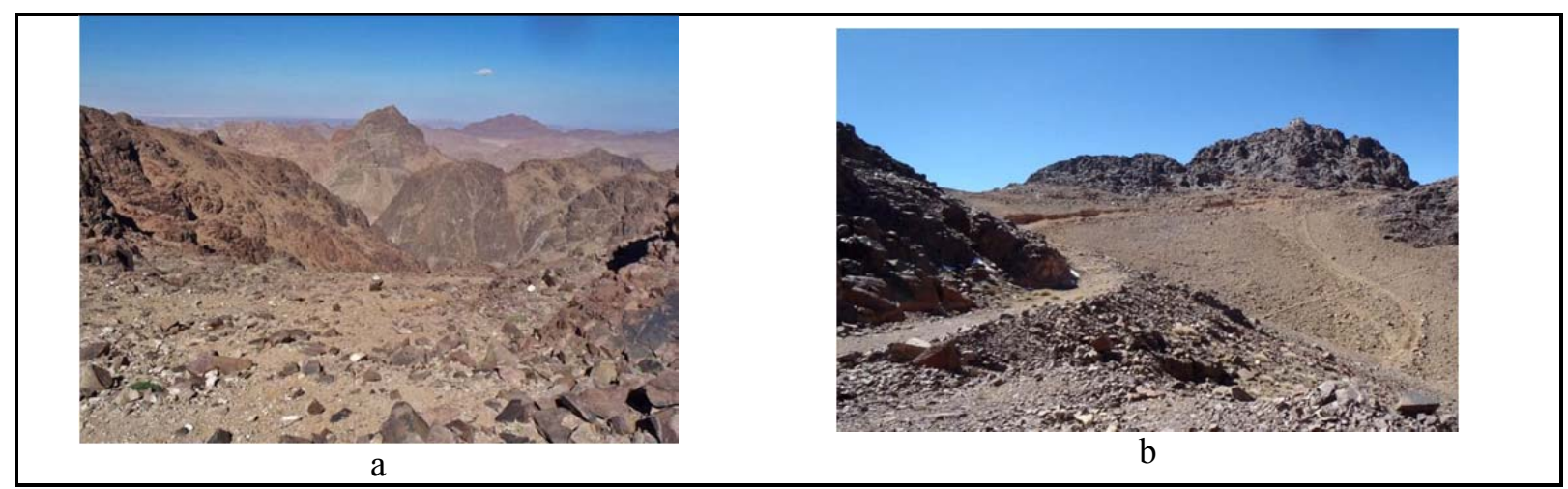

Fig. 3: (a) General view of W. Al-Shaq (Farsh Umm Silla). (b) Top of G. Katherina, old army road.

The Rutig succession at Gebal Katharina is unconformably overlain by the alkaline volcanic of the Katharina Ring Complex, and are intruded by the c. 583 Ma Katharina pluton of the same complex (Katzir et al., 2007; Be'eri-Shlevin et al., 2011). Based on field relationships, the Rutig succession can be divided into two major units, the lower and upper Rutig. The lower Rutig comprises volcanic flows and pyroclastics interbedded with agglomerates.

The volcanic interbeds at W. Rutig are dominantly tuffs, with minor lava flows and volcanic breccia. The upper Rutig unit rests unconformably on top of the lower Rutig section. It dips gently north and shows minor intrusion by dikes. As with the lower Rutig, the upper Rutig section includes few volcanic flows, while the sedimentary layers include conglomerates and sandstones. A conglomerate layer is located at the top of the section in W. Rutig below its unconformable contact with the overlying alkaline volcanics of the Katharina Ring Complex. The conglomerate consists of cobbles and pebbles of a variety of rock types set in a finer matrix. The rock clasts are dominated by large (up to $50 \mathrm{~cm}$ ) volcanic cobbles, though fragments of granite and diorite have also been detected. The dominant volcanic rock fragments include rhyolites, dacites, andesites and pyroclastics, but clearly dacite is the commonest lithology. 


\section{Imbarak, S. H. and Al-Rashed, A. R.}

The Pyroclastics occur as thick beds alternating with minor lava flows. The early- formed pyroclastics, however, are inter-fingered with the conglomerates. The bulk of the pyroclastics are classified as tuffs because the average grain size of their pyroclasts is less than two millimeters. Less common coarser-grained pyroclastics include lapillistone and volcanic breccia. Pyroclastic rocks comprise lava flows, pyroclastic, rhyolitic ignimbrite, volcanic breccia, and peralkaline ignimbrite, flows of rhyolitic ignimbrite (El Masry 1991 and Eyal 2014). Volcanic breccia composed of angular rock fragments, embedded in crystal-rich rhyolite tuff, overlying the rhyolitic ignimbrite. Peralkaline ignimbrite builds the upper part of the section east of the Gebel Katherina peak (Fig. 4).

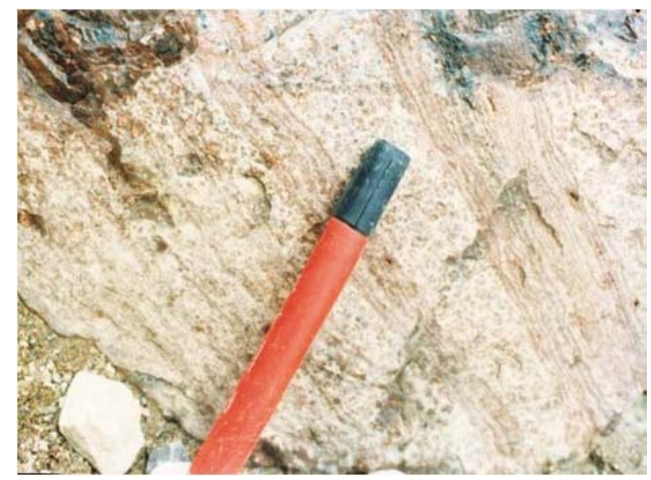

(a)

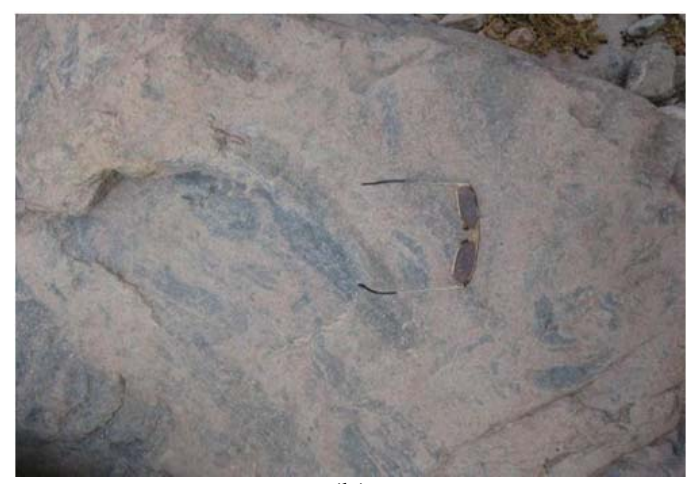

(b)

Fig. 4: Close-up views showing ignimbrite outcrop (a) and tuffs on the volcanic rocks (b).

Volcanic agglomerates are coarse grained igneous rocks with rounded to subangular fragments mainly larger than $2 \mathrm{~cm}$ in size, unsorted and set in a fine matrix. Agglomerate is a very hard pyroclastic unit with large clasts (Fig. 5a). It occurs as two to four beds, each 5-10 m thick, of massive hard rock. The clasts are from $15 \mathrm{~cm}$ to $50 \mathrm{~cm}$-sized and with an average of $20 \mathrm{~cm}$. The unit is associated with thin basaltic dikes and flows (Fig. 5b). The pyroclastics are more than $90 \%$ juvenile, with $60 \%$ matrix and $30 \%$ clasts ( $20 \%$ scoria, $5 \%$ pumice and $5 \%$ crystals).

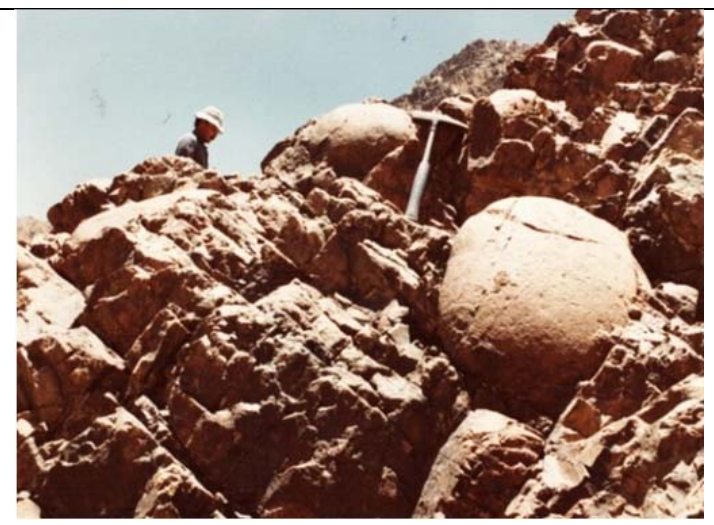

a

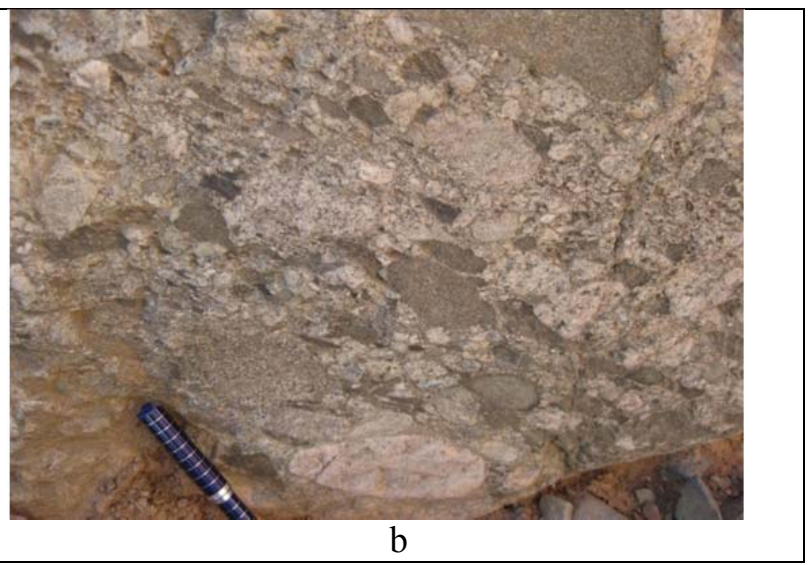

b

Fig. 5: a) General view of volcanic agglomerates composed of rounded to sub-angular fragments mainly larger than $2 \mathrm{~cm}$ in size, unsorted and set in a fine and pyroclastic tuffs. b) Agglomerate rounded clasts to subangular in a matrix of lava or ash.

The epiclastic rocks include conglomerates, sandstones, and mudstones. Consecutive thick beds of conglomerates dominate the upper part of the epiclastic succession alternating with early-deposited pyroclastics (Fig. 6a). Sandstones are considered as the main constituent of the epiclastic succession, whereas mudstones are less frequently encountered (El Masry, 1991 and El-Masry and Hegazi, 2005).

\section{Field occurrence of zeolites}

The spatial distribution of zeolites and other secondary minerals in the tuffs and other pyroclastic rocks is controlled by host rock chemical composition and local hydrothermal conditions (Hassan and 
Al-Rashed, 2017). Host rock porosity controls the fluid/rock interaction. A typical example of zeolite occurrence in amygdules volcanics and pyroclastics can be observed in the Rutig Volcanics (Fig. 6b). These are dark gray spilitic basaltic- andesites. They are banded or massive green basalts, and spheroidal weathered gray to reddish basaltic- andesites (Fig. 6c and d). The weathering is weak, penetrating into cavities and yielding zeolites concentration.

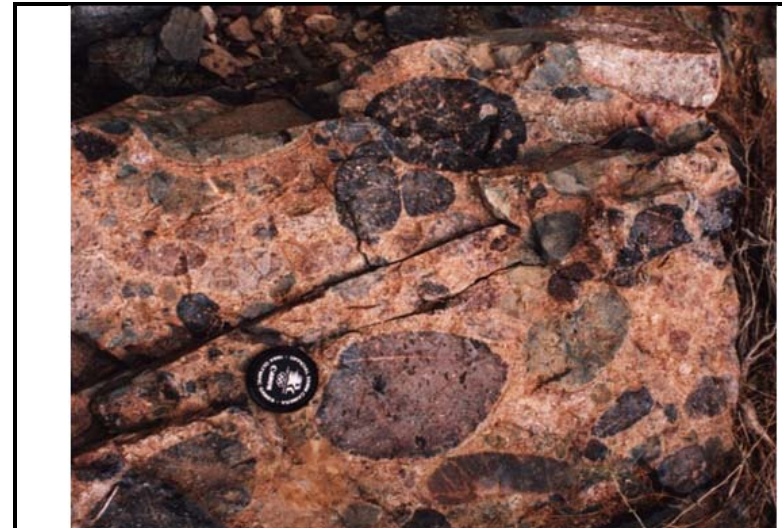

a

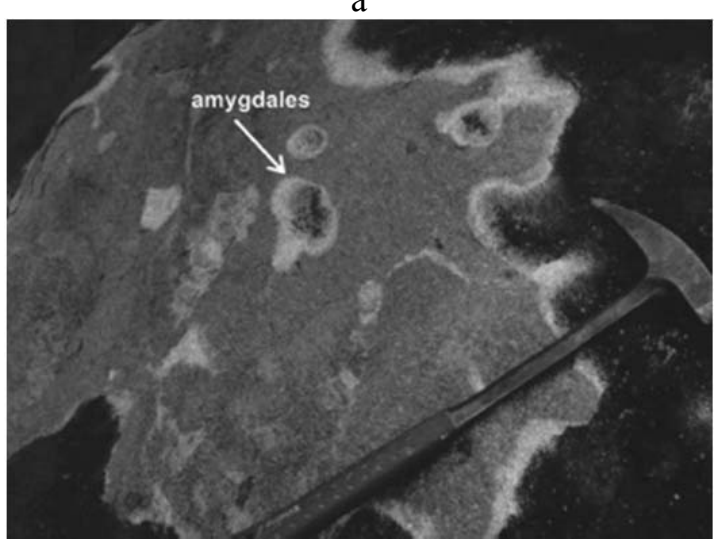

c

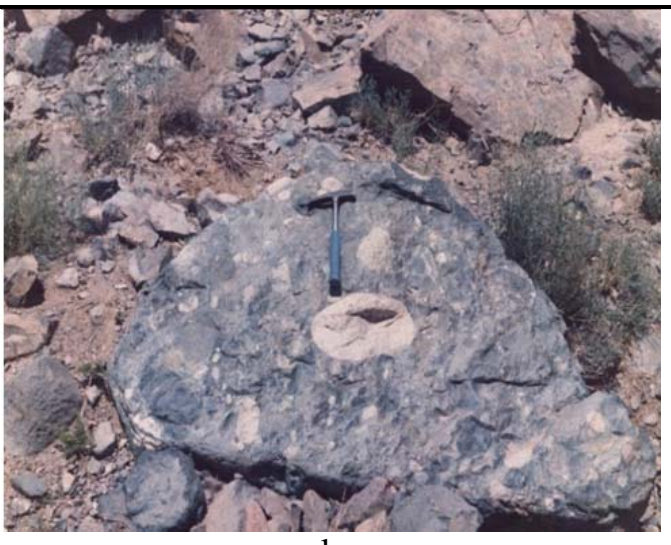

b

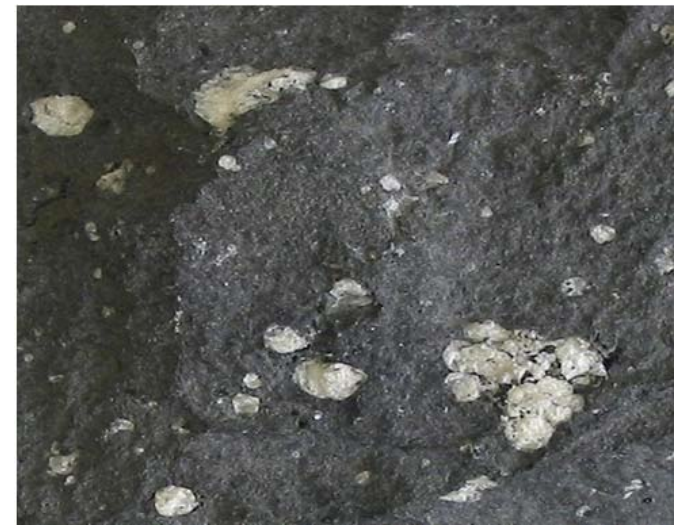

d

Fig. 6: a) Bimodal oligomictic ortho-conglomerate composed of volcanic clasts set in a medium- to coarsegrained sandstone matrix. b) Outcrop-scale features illustrating the occurrence of zeolite-bearing pyroclastic rock in Vesicular structure; W. Rutig. c) Amygdaloidal volcanic rocks showing zeolite cavity filling. d) Zeolite minerals filling amygdules in the volcanic rocks.

\section{MATERIALS AND METHODS}

Field geological observations, petrographic descriptions, and mineralogical and chemical examinations were made on the features of the volcanics, tuffs, pyroclastic rocks and vugs, in order to provide some information on their weathering history. The petrographic observation (identification of the various mineralogical phases, their quantification and the microstructural description of the materials) were made with polarizing microscope on thin sections. X-ray diffraction (XRD) on random powders was performed using a Siemens Bruker unit with $\mathrm{Cu} \mathrm{K \alpha}$ anticathode.

The sizes and morphological features of the sub- microscopic zeolite minerals and their interrelations with other minerals were determined using scanning electron microscopy (SEM).

\section{RESULTS}

Zeolites, quartz, and calcite are found in amygdaloidal volcanics at Gabal Katherina area, where the principal zeolite minerals are phillipsite, gismondine, chabazite, gonnardite, natrolite, analcime, aujasite and thomsonite. 
Imbarak, S. H. and Al-Rashed, A. R.

\section{Petrograpic features and mineralogy}

The texture of the pyroclastics material is intermediate between clast- supported and matrixsupported, with randomly oriented clasts. The welded pyroclastic rocks consist of light grey clasts in a greenish grey matrix. The volcanic ash from the eruption of Katherine volcanics is relatively homogeneous at the scale of the deposit, presenting only limited local variations in particle size grading. The glassy matrix was mostly tuffaceous and may show signs of devitrification. The matrix includes pumice fragments, spherulites, elongated sharp or platy shards of glass, pieces and splinters of glassy rock, and fibrous chalcedony.

Rhyolitic ignimbrite is a dark gray to dark brown rock, composed of broken oligoclase phenocrysts flattened pumice and angular volcanic rock fragments, embedded in a devitrified microcrystalline to the fine-grained matrix, which consists of quartz, alkali feldspar and ore minerals.

Alkali ignimbrite is black fluidal rhyolite porphyry with medium-grained phenocrysts of perthite and quartz. The matrix is a devitrified glass consisting of quartz and alkali-feldspar, with flow-oriented shards and flattened pumice 1 to $15 \mathrm{~mm}$ in length. Aegirine prisms occur in rounded clusters $3 \mathrm{~mm}$ in diameter and riebeckite as subhedral crystals $0.03 \mathrm{~mm}$ across. In some ignimbrite flows, rare prismatic plagioclase phenocrysts are observed (Fig. 7a)

Vitrophyric and partially porphyritic textures were identified in the ignimbrite and volcanic rocks. Plagioclase and augite were also found as microlites and phenocrysts in the pyroclastics (Fig. 7b).

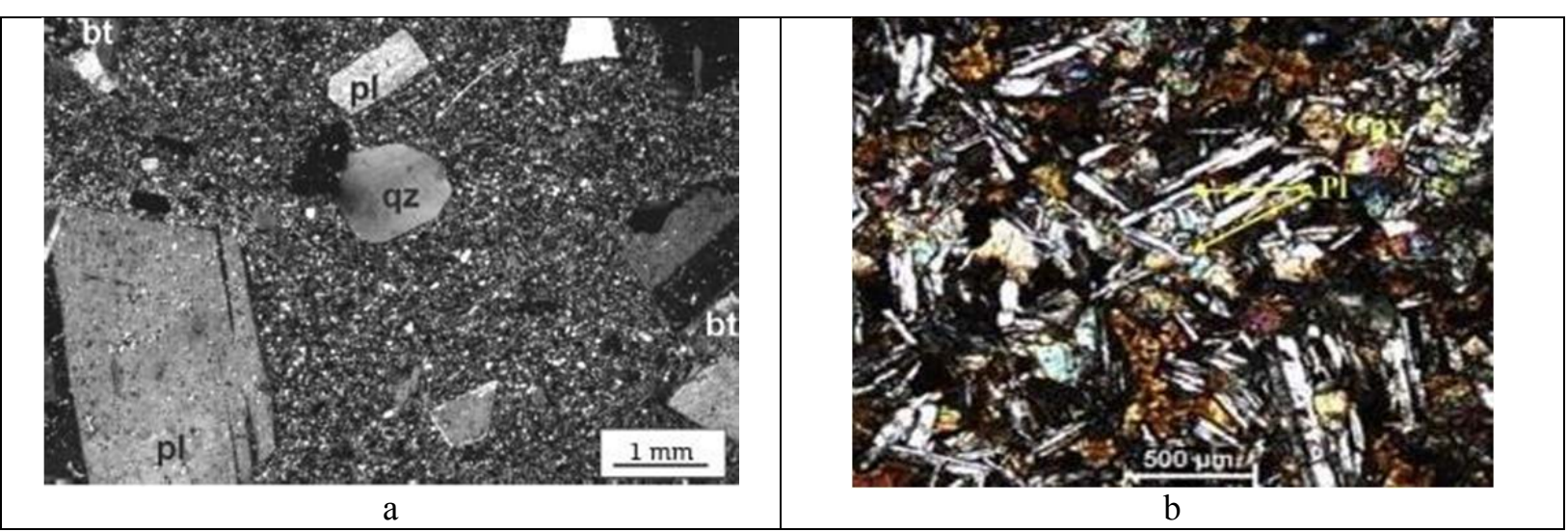

Fig.7: a) Photomicrographs showing: b) porphyritic to glomero- porphyritic texture within basalticandesites. (B) Clustered plagioclase-phenocrysts forming glomero-porphyritic texture.

Tuffs generally have black, brownish-black, and dark grey colors. The main components of a tuffaceous rock usually include crystals or crystal fragments, lithic fragments, and compressed pumice fragments and glass shards (Fig. 8a).

The composition of volcanic ash and breccia of rhyolite comprises angular rock fragments of ignimbrite, spherulitic alkali rhyolite, vitrophyric quartz porphyry, trachyte, and granite. The matrix is a crystal-rich rhyolite tuff consisting of microcrystalline quartz and alkali feldspar, with subhedral phenocrysts of oligoclase and minor quartz (Fig. 8b).

Vesicles and amygdules are conspicuous in many tuffs and agglomerates, especially at the basal parts of the pyroclastics that immediately overlie the conglomerates. Most of the amygdales are ellipsoidal and are filled either partly or completely with secondary minerals such as quartz, calcite, laumontite (Fig. 9a), smectite and zeolite (Fig. 9 b and c). 
Zeolite-bearing amygdaloidal volcanic and volcanoclastic rocks

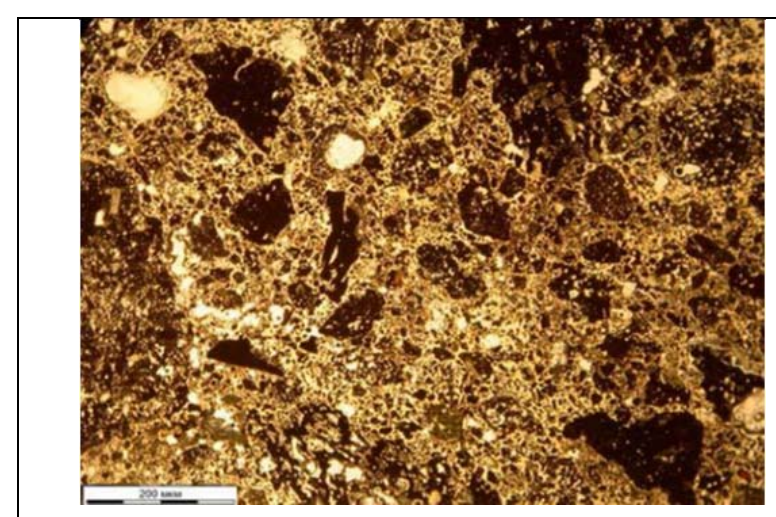

a

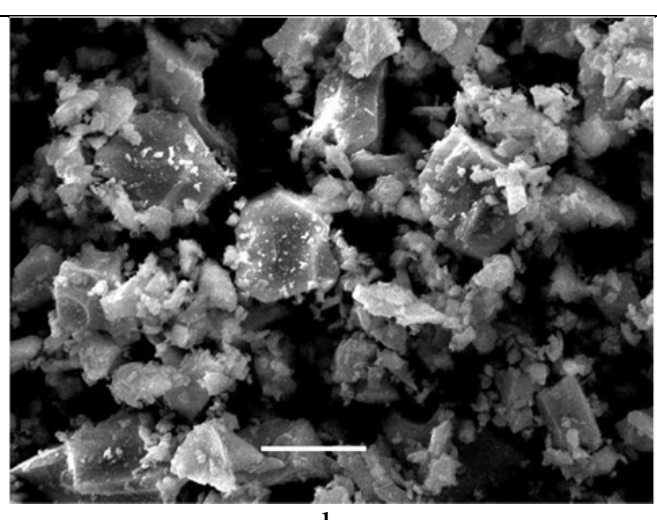

b

Fig. 8: a) Photomicrograph showing tuffaceous rock composed of crystals, fragments, lithic fragments, and show pumiceous texture in glass shards. b) Back-scattered image showing volcanic ash from the eruption of Katherne volcanics.

The andesitic-dacitic and rhyodacites are porphyritic with quartz, alkali feldspar, plagioclase, biotite and opaque grains of, probably, highly resorbed biotite or amphibole, Fe-Ti oxides, apatite and zircon as accessories minerals. The dacites are also porphyritic with a major mineral assemblage formed by quartz, oligoclase, alkali feldspar, calcic amphibole and biotite, and an accessory assemblage consisting of apatite, Fe-Ti oxides and titanite. The basaltic- andesite is made of a fine-grained intergranular aggregate with abundant plagioclase, Ti- augite, calcic amphibole, scarce biotite and accessory $\mathrm{Fe}-\mathrm{Ti}$ oxides and apatite It is apparent that matrix is more altered than mineral phase (Fig. $9 \mathrm{c}$ and d).

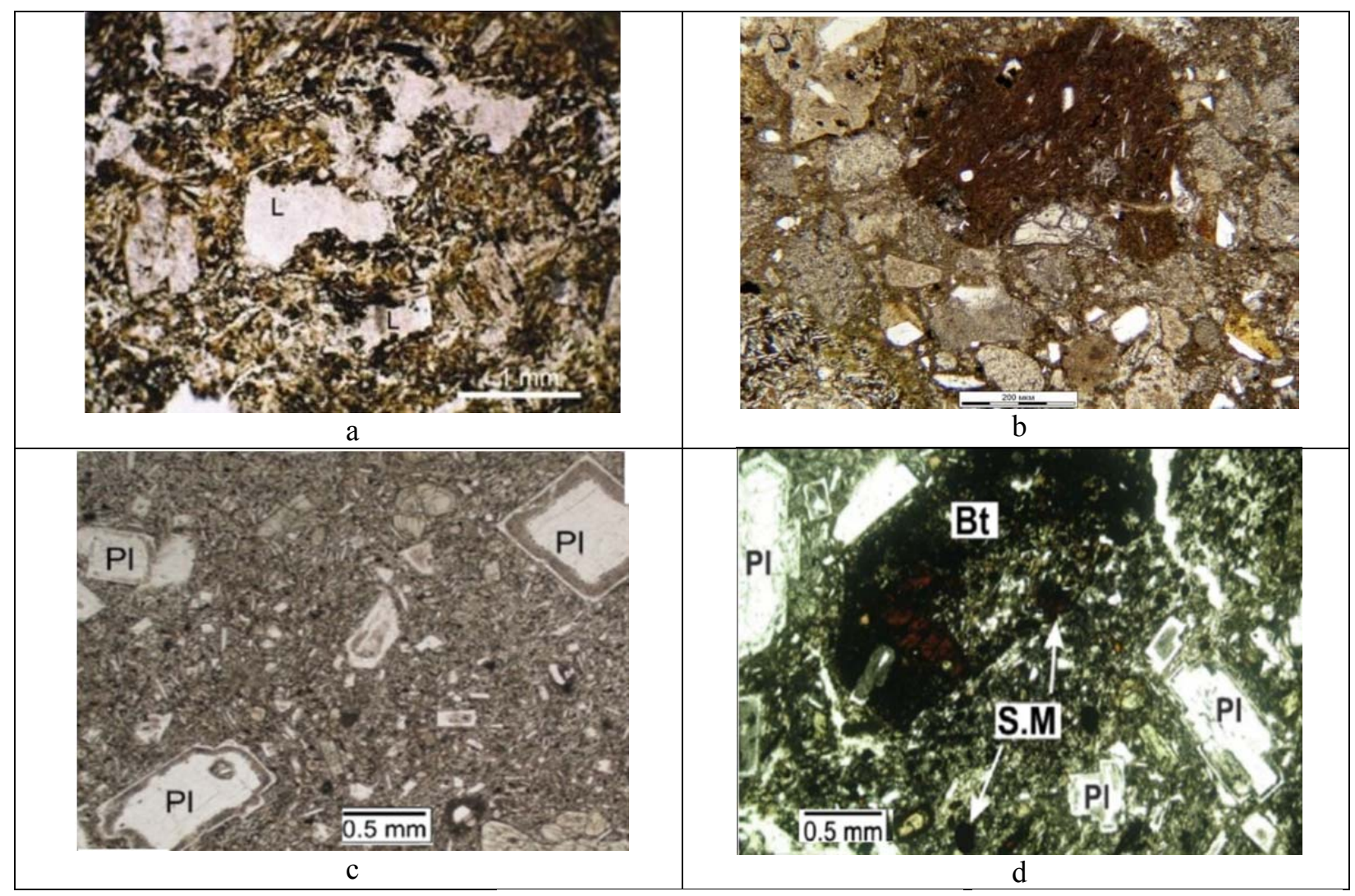

Fig. 9: a): Photomicrograph showing amygdules filled with laumontite (L). b) Vesicles filled with quartz, feldspar, zeolite and smectite aggregate. c) Plagioclase shows euhedral shapes and less alteration. d) More altered plagioclase $(\mathrm{Pl})$ associated with more altered matrix than original mineral phase; biotite $(\mathrm{Bt})$ is found as secondary minerals. 
Imbarak, S. H. and Al-Rashed, A. R.

Various alteration types (Fig. 10), such as epidotization and saussuritization (Fig. 10a and b), albitization and chloritization (Fig. 10c), carbonatization, argillitization (Fig. 10d), oxidation and silicification have been developed by effecting hydrothermal processes during fluid rock interaction. Albitization of the primary plagioclase in the volcanoclastic rocks is common throughout the sequence, by replacement of the original plagioclase by a more sodic variety which may vary in composition from albite to oligoclase. During this replacement, the twinning characteristics of the primary plagioclase are inherited, but zoning is obliterated.

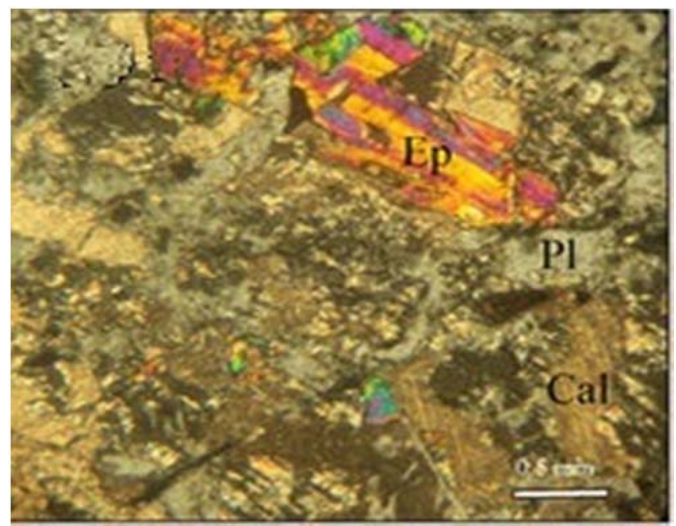

a

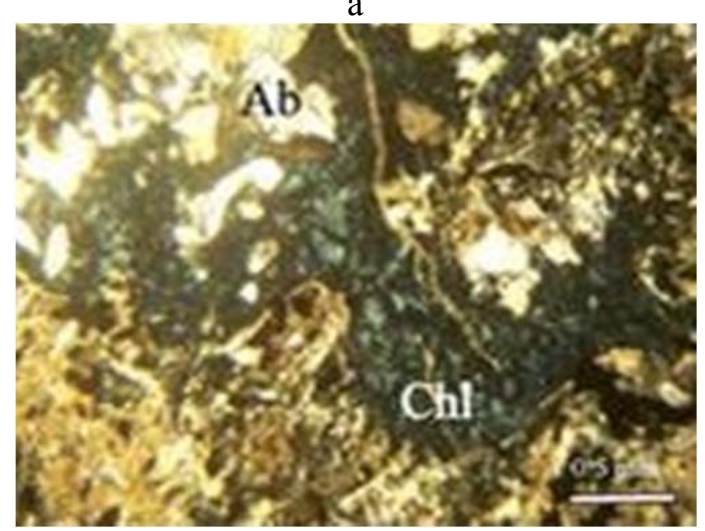

c

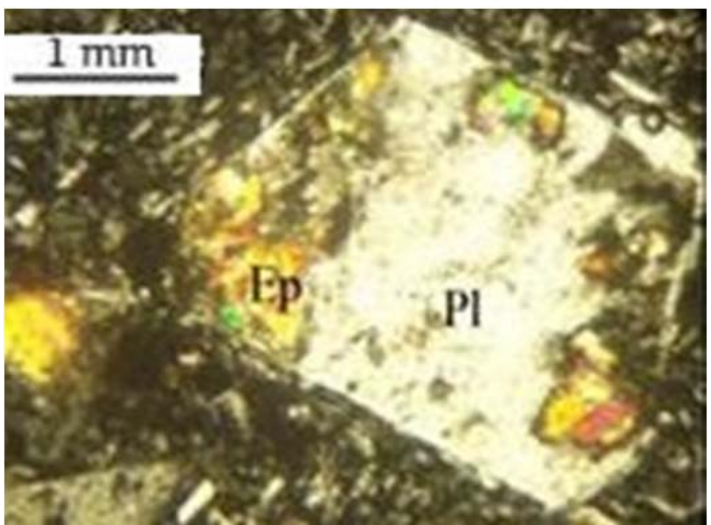

b

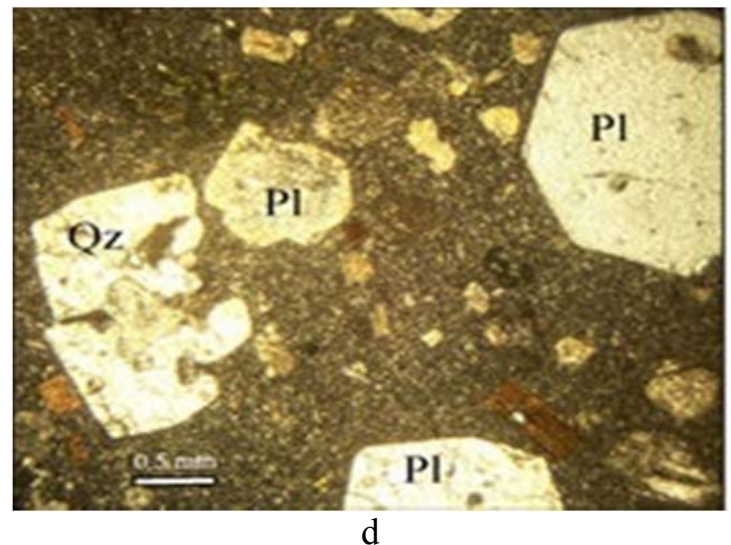

Fig. 10: Photomicrograph showing (a) Epidotization and Saussuritization. (c) Albitization and chloritization of volcanic rocks. (d) Argillitization and silicification of volcanic rocks.

Zeolites appear filling cavities in a non-uniform way in places, they fill cavities completely and show honeycomb structure (Fig. 11a). They are usually about $0.5-1.5 \mathrm{~cm}$ in diameter but can locally reach up to $10 \mathrm{~cm}$. Drusy amygdales, having a partial filling, may exhibit various zeolite materials. Radial aggregates of zeolites with vitreous luster usually occur in irregular amygdules of variable shape and size (Fig. 11B).

They are associated with other secondary minerals such as amorphous silica, calcite and nontronite. Zeolites are also found in fibrous aggregates, partly or completely filling spheroid, ellipsoidal or irregular amygdales. Amygdules have a spheroid, ellipsoidal or irregular shape.

Zeolite minerals usually occur as microcrystalline aggregates that are generally associated with smectite, feldspar, silica, and some carbonate minerals with laumontite filling vesicles. Smectite and calcite are the most common non -zeolite minerals in the clay, silt, and carbonate layers. Albite, quartz, mica are mostly found in mudstones, illite; while analcime, thomsonite, quartz and calcite characterize the clay, silt, and carbonate layers that are interlayered with the zeolitic tuffs. 
Zeolite-bearing amygdaloidal volcanic and volcanoclastic rocks

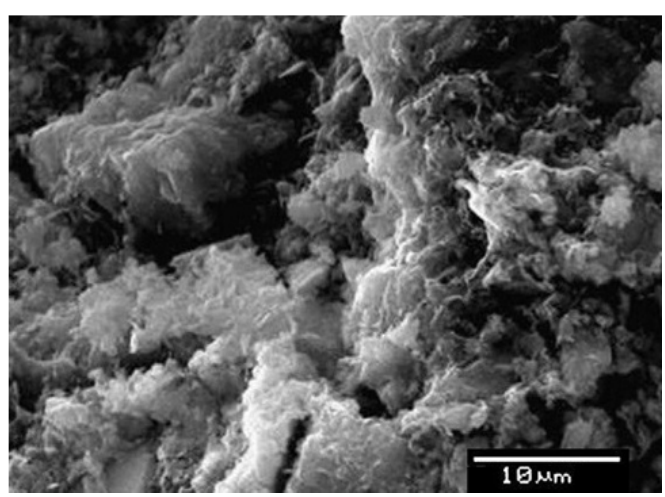

a

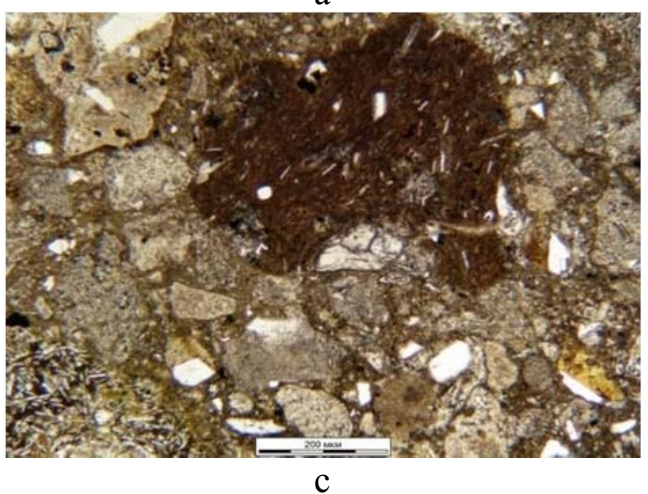

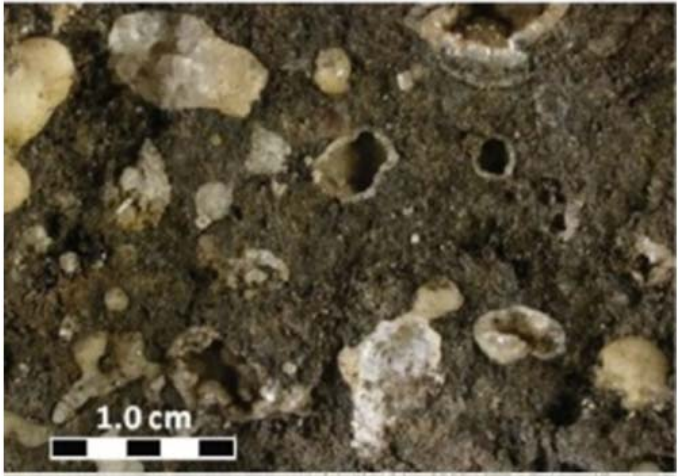

b

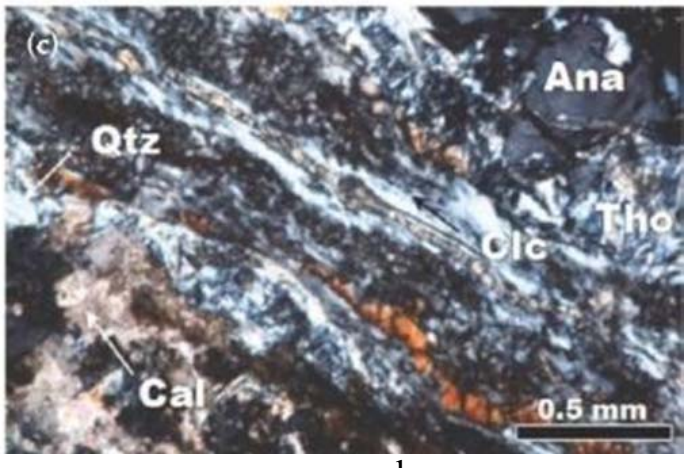

d

Fig. 11: a) Back-scattered image of zeolite showing honeycomb-like structure. b) Amygdules have a spheroid, ellipsoidal or irregular shape. c) Photomicrograph of quartz, feldspar, zeolite and smectite aggregate. d) Photomicrograph of analcime (Ana), Thomsonite (Tho) quartz (Qtz) and calcium (cal).

Analcime that is considered as a primary mineral of late formation occurs in some tuffaceous rocks. It occurs as small globules in inclusions of analcime trachy-basalt and trachy-andesite. Analcime is known as a primary constituent in some basalts and basaltic-andesites, where it is typically restricted to the groundmass (Fig. 11D). Phillipsite occupies cracks and also occurs in fibrous aggregates, partly or completely filling spheroid, ellipsoidal or irregular amygdales Irregular to ellipsoidal shaped amygdales (up to $2.0 \mathrm{~cm}$ ) may be completely filled by crystals, revealing the occurrence of at least two zones: a fibrous lining in the outer part of the cavity wall and a fibrous interior padding.

The volcanic tuffs contain abundant tabular clinoptilolite and phillipsite crystals that formed by the replacement of vitric particles. Chabazite is confined to the vesicles and appears as transparent crystal aggregates. Chabazite rhombohedra form mantles on phillipsite rims. Generally, chabazite is found together with calcite and grows in pyroclastics that include remnant leucite grains. Phillipsite is always found as a thin rim lining the vesicles. Phillipsite occurs mainly as white rosettes of radiating and spherulitic crystal aggregates.

\section{Metamorphism}

Wide variety of metamorphic, alteration products occurs in the volcanics and volcaniclastic rocks of the Rutig volcanic. They partly replace phenocrysts, fragments, shards, and groundmass, and crystallize in amygdules, pore spaces and veins. Many types of secondary minerals have formed in the rocks of the Rutig volcanic. These associations are rarely formed in the rocks of the Rutig volcanic because most are acidic in composition and are unsuitable for the growth of low-grade index minerals.

The zeolite and prehnite-pumpellyite facies are considered burial metamorphism as the processes of orogenic regional metamorphism is not required. Generally, volcanic rocks are not greatly affected by zeolite facies metamorphism, although vesicular basaltic andesite and the like will have their vesicles filled with zeolite minerals, forming amygdules texture. Tuffs also becomes zeolitized. Piedmontite and stilpnomelane (needle-like aggregates) recorded in chloritized groundmass (Fig. 12). 
Imbarak, S. H. and Al-Rashed, A. R.
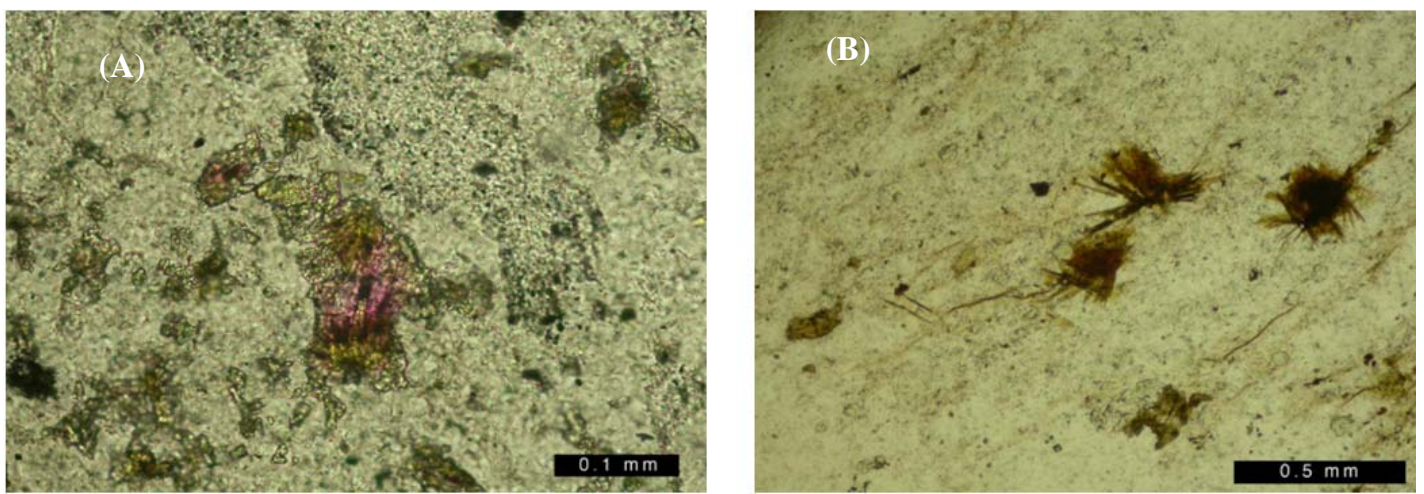

Fig. 12: a) Photomicrograph of piedmontite in chloritized groundmass of tufficeus sample. b) Photomicrograph of metamorphic stilpnomelane (needle-like aggregates) in plane-polarized light.

Thus the mineralogical characteristics of this volcanics are not well known. A feature of many of the volcanoclastic rocks is the presence of amygdules containing more than one metamorphic mineral phases. The most common phases are quartz, chlorite, calcite, zeolite, and epidote; less common are prehnite, pumpellyite, white mica, and mixed-layer clays. Sometimes; quartz appears as chalcedonic spherulites or as well- defined euhedral crystals. Spherulites could have grown from a silicarich.

\section{X-Ray Diffraction Analysis}

Both qualitative and quantitative XRD methods were used in this research. The mineralogical composition of the amygdaloidal volcanics and tuffs was determined by XRD analysis. Qualitative XRD analysis involves identifying the varieties of zeolite species. These are found to be analcime, as the dominant zeolitic phase, followed by chabazite, natrolite, thomsonite, wairakite, stilbite, stilbite$\mathrm{Ca}$, phillipsite and stellerite- $\mathrm{Na}$, thomsonite- $\mathrm{Ca}$, chabazite-Ca and chabazite-Na, with minor stellerite, phillipsite-Na, and gyrolite. Other secondary minerals associated with zeolites were celadonite (Fe-rich mica), nontronite (Fe-rich smectite), greigeite (iron sulfide mineral), koninckite or bobierrite (phosphates), alunite (sulphate), truscottite (silicate), calcite or dolomite, and quartz. Nontronite was found in most samples (Fig. 13).
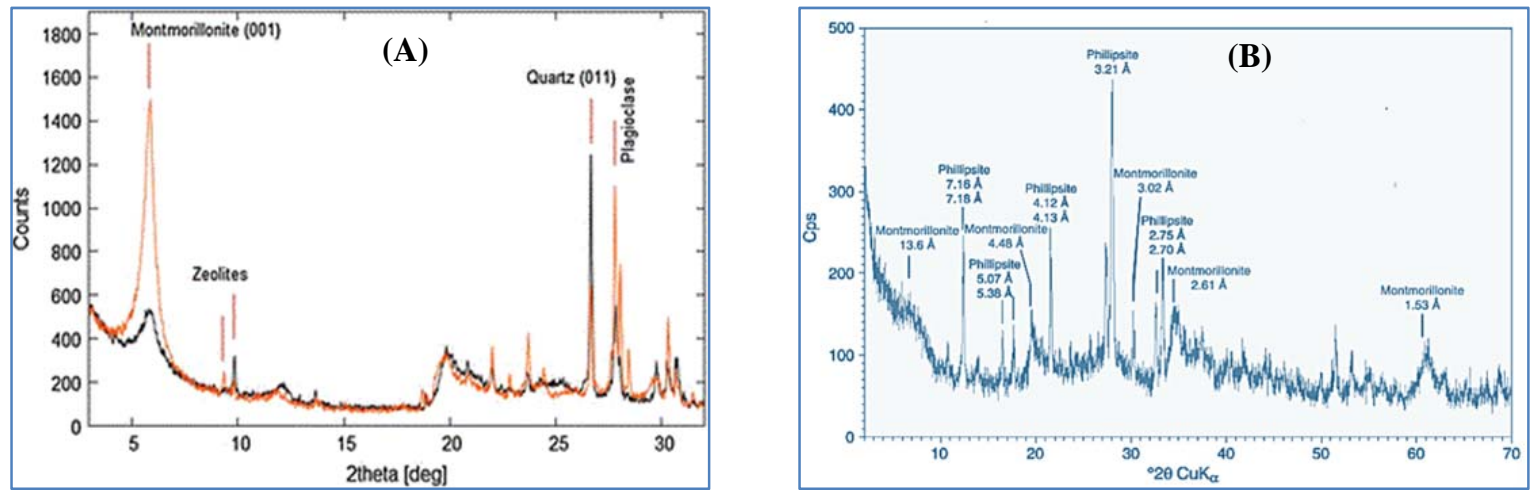

Fig. 13: A. XRD diffractogram shows a peak of zeolite mineral composition. (B). XRD diffractogram of amygdaloidal zeolitic pyroclastic volcanic zeolites.

\section{Scanning Electrical Microscopy SEM Analysis}

Scanning Electron Microscopy (SEM) is used to examine volcanic amygdules and ash, to discover the varieties of zeolitic minerals and their contents in volcanic rocks. The main zeolites were analcime, phillipsite, clinoptilolite, thomsonite and chabazite. 


\section{Zeolite-bearing amygdaloidal volcanic and volcanoclastic rocks}

Under SEM, the volcanic ash shows evidence of angular glassy shards, and zeolites, which are developed in pores and fractures. They form crystals of regular geometric shape such as tabular, prismatic, and fibrous crystals.

Fibrous mordenite is the only observed zeolite in samples from the volcanic amygdules. Clinoptilolite- mordenite associations grow in soils around volcanics tuffs. Phillipsite occurs either as spherulitic radiating aggregates or stout-prismatic crystals. Chabazite occurs in colorless rhombohedra with simple penetration twinning. Thomsonite forms typical radial fibrous aggregates in the other part of the cavity wall, followed by natrolite occurring as fine fibers (Figs. 16 A- F).
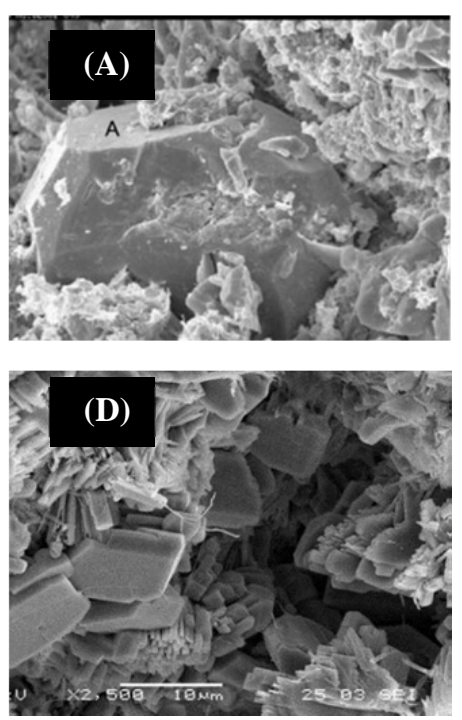
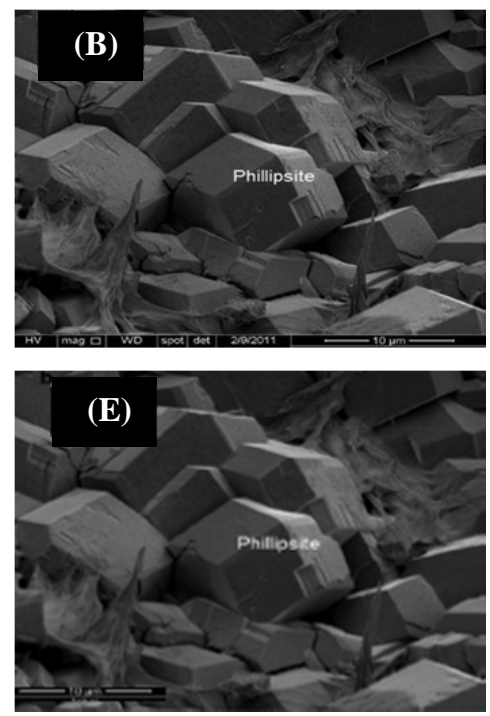
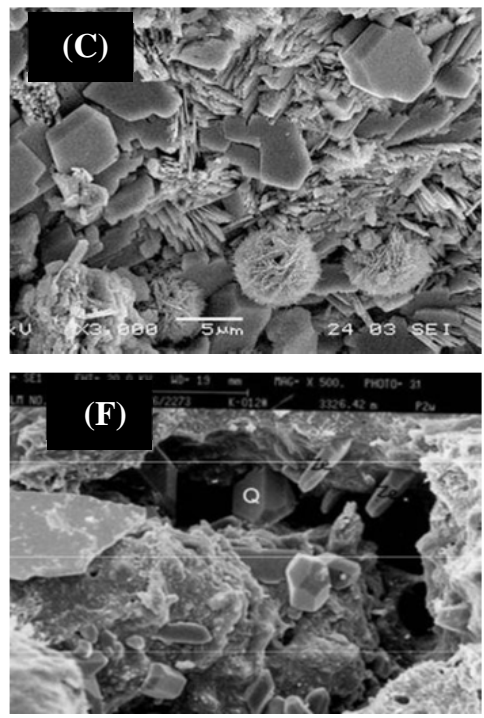

Fig. 14: SEM photomicrographs of typical different zeolite contents in volcanic rocks; (A) SEM images of isometric granular analcime. (B) SEM images of phillipsite crystals. (C) SEM images of Clinoptilolite crystals. (D) SEM images of glass shards. clinoptilolite crystals. (E) SEM images of Philise crystals. (F) Authigenic quartz (Q) and wedge-like zeolite minerals.

\section{GEOCHEMISTRY}

Based on microprobe and thin section examinations of the fresh lavas and tuffs, the plagioclase minerals consisted mainly of oligoclase and, to a lesser extent, of andesine which indicate that these volcanics are mainly intermediate in composition. Whole rock chemical compositions analyses were made on some representative tuffs and pyroclastic volcanics from Gabal St. Katherine area (Table 1).

The analyzed samples show a remarkable homogeneity in their mineralogical and chemical composition. They are characterized by low $\mathrm{SiO}_{2}$ content with a very wide range of variations from $21.6 \%$ to $40.10 \%$ decrease with increasing degree of alteration.

The $\mathrm{Al}_{2} \mathrm{O}_{3}$ wt. $\%$ in the studied samples lies between $7.69 \%$ and $12.8 \% . \mathrm{Al}_{2} \mathrm{O}_{3}$ wt. $\%$ versus $\mathrm{SiO}_{2}$ wt. \% (Fig. 15a), and total alkalis $\left(\mathrm{Na}_{2} \mathrm{O}+\mathrm{K}_{2} \mathrm{O}\right.$ wt. \%) versus $\mathrm{SiO}_{2}$ wt. \%, show positive correlations, indicating that they exhibited similar geochemical behavior under the zeolitization processes (Fig. 15b).

The inverse relationship between $\mathrm{SiO}_{2}$ wt. percent versus LOI content is well illustrated in Figure $(17 \mathrm{c})$. This fits with the samples being highly altered and displaying several stages of alteration. This is also supported by field evidence, including occurrences of abundant zeolites and calcite in the volcanic tuff, occurring as cement in the volcanic clasts. The presence of high $\mathrm{CaO}$ wt. \% in selected samples up to $24.9 \%$ indicates presence of abundant carbonates. The other important constituents of the samples are $\mathrm{Fe}_{2} \mathrm{O}_{3}$ and $\mathrm{MgO}$. Specifically, $\mathrm{Fe}_{2} \mathrm{O} 3$ ranges from $6.26 \%$, to $13.5 \%$, whereas the $\mathrm{MgO}$ ranges from $6.26 \%$, to $13.5 \%$. 
Imbarak, S. H. and Al-Rashed, A. R.

Table 1.Chemical compositions of the volcanic rocks and bentonite in the study area.

\begin{tabular}{|c|c|c|c|c|c|c|}
\hline Sample & Basalt & Trachy-andesite & Hb- andesite & Dacite & Tuff & Cha \\
\hline Element & $n=2$ & $n=3$ & $n=4$ & $n=6$ & $\mathbf{n}=3$ & $n=2$ \\
\hline $\mathrm{SiO}_{2}$ & 50.41 & 60.63 & 60.59 & 64.79 & 63.51 & 56.8 \\
\hline $\mathrm{Al}_{2} \mathrm{O}_{3}$ & 15.9 & 17.15 & 16.23 & 16.01 & 14.7 & 14.04 \\
\hline $\mathrm{Fe}_{2} \mathrm{O}_{3}$ & 8.85 & 5.58 & 5.76 & 4.47 & 3.29 & 0.48 \\
\hline $\mathrm{MgO}$ & 6.47 & 1.51 & 2.79 & 1.7 & 1.81 & 2.72 \\
\hline $\mathrm{CaO}$ & 8.97 & 5.03 & 6.14 & 4.96 & 4.17 & 1.74 \\
\hline $\mathrm{Na}_{2} \mathrm{O}$ & 3.56 & 4.78 & 3.82 & 3.8 & 2.74 & 2.42 \\
\hline $\mathrm{K}_{2} \mathrm{O}$ & 1.88 & 1.87 & 1.69 & 1.54 & 1.64 & 1.28 \\
\hline $\mathrm{TiO}_{2}$ & 1.41 & 1.01 & 0.79 & 0.54 & 0.46 & 0.08 \\
\hline $\mathrm{P}_{2} \mathrm{O}_{5}$ & 0.6 & 0.48 & 0.4 & 0.27 & 0.26 & 0.01 \\
\hline $\mathrm{MnO}$ & 0.14 & 0.06 & 0.09 & 0.06 & 0.04 & 0.01 \\
\hline $\mathrm{Cr}_{2} \mathrm{O}_{3}$ & 0.02 & 0.02 & 0.02 & 0.02 & 0.01 & 0.002 \\
\hline LOI & 1.6 & 1.74 & 1.53 & 1.74 & 7.27 & 20.08 \\
\hline Total & 99.87 & 99.84 & 99.83 & 99.88 & 99.8 & 99.66 \\
\hline $\mathrm{Ba}$ & 580 & 598 & 755 & 627 & 470 & 1618 \\
\hline $\mathrm{Co}$ & 34.3 & 11.99 & 15.37 & 10.43 & 4.54 & 3.02 \\
\hline $\mathrm{Cs}$ & 2.78 & 1.24 & 1.61 & 1.8 & 4.38 & 1.1 \\
\hline $\mathrm{Ga}$ & 16.98 & 17.73 & 18.04 & 17.33 & 14.56 & 7.9 \\
\hline Hf & 3.88 & 4.14 & 3.63 & 3.45 & 2.94 & 3.62 \\
\hline $\mathrm{Nb}$ & 21.78 & 18.47 & 13.57 & 10.01 & 7.5 & 13.34 \\
\hline $\mathrm{Rb}$ & 43.02 & 40.83 & 41.8 & 36.7 & 25.96 & 21.78 \\
\hline $\mathrm{Sr}$ & 874 & 590 & 698 & 564 & 406 & 1107 \\
\hline $\mathrm{Ta}$ & 1.32 & 1.2 & 0.84 & 0.69 & 0.52 & 1.96 \\
\hline $\mathrm{Th}$ & 6.28 & 6.19 & 8.46 & 8.35 & 6.04 & 32.16 \\
\hline $\mathrm{U}$ & 1.42 & 1.76 & 2.39 & 2.56 & 1.48 & 1.02 \\
\hline $\mathrm{V}$ & 180 & 103.7 & 111.9 & 80.4 & 52.6 & 13 \\
\hline $\mathrm{Zr}$ & 152.9 & 160.69 & 136.25 & 119.31 & 72.7 & 78.52 \\
\hline$Y$ & 24.24 & 20.13 & 18.65 & 15.03 & 12.14 & 4.06 \\
\hline $\mathrm{La}$ & 36.82 & 32.23 & 35.1 & 31.01 & 20.42 & 25.84 \\
\hline $\mathrm{Ce}$ & 68 & 58.64 & 63.19 & 53.65 & 38.58 & 45.4 \\
\hline $\operatorname{Pr}$ & 7.9 & 6.53 & 6.91 & 5.68 & 3.89 & 4.14 \\
\hline $\mathrm{Nd}$ & 31.34 & 24.7 & 26.34 & 20.79 & 13.88 & 12.32 \\
\hline $\mathrm{Sm}$ & 5.62 & 4.51 & 4.51 & 3.57 & 2.09 & 1.92 \\
\hline $\mathrm{Eu}$ & 1.68 & 1.27 & 1.22 & 0.98 & 0.66 & 0.26 \\
\hline $\mathrm{Gd}$ & 5.24 & 3.79 & 3.88 & 2.88 & 1.87 & 1.42 \\
\hline $\mathrm{Tb}$ & 0.72 & 0.58 & 0.56 & 0.44 & 0.26 & 0.22 \\
\hline Dy & 4.22 & 3.34 & 3.23 & 2.51 & 1.32 & 0.94 \\
\hline Ho & 0.9 & 0.72 & 0.6 & 0.46 & 0.26 & 0.16 \\
\hline Er & 2.37 & 1.88 & 1.74 & 1.4 & 0.75 & 0.36 \\
\hline $\mathrm{Tm}$ & 0.36 & 0.29 & 0.27 & 0.2 & 0.11 & 0.06 \\
\hline $\mathrm{Yb}$ & 2.19 & 1.78 & 1.7 & 1.44 & 0.69 & 0.32 \\
\hline $\mathrm{Lu}$ & 0.31 & 0.29 & 0.26 & 0.21 & 0.11 & 0.06 \\
\hline REE & 167.7 & 140.6 & 149.5 & 125.2 & 84.88 & 93.32 \\
\hline LRE & 144.1 & 122.1 & 131.5 & 111.1 & 76.77 & 87.7 \\
\hline HRE & 5.23 & 4.24 & 3.97 & 3.25 & 1.65 & 0.76 \\
\hline
\end{tabular}

Geochemical plots of $\mathrm{Nb} / \mathrm{Y}$ vs. Zr/Ti (Pearce, 1996) for the examined rocks indicate that the zeoliterich tuffs plot near the boundary between the basaltic andesite and rhyodacite-dacite fields (Fig. 16). On the $\mathrm{Zr} / \mathrm{TiO}_{2}$ vs $\mathrm{SiO}_{2}$ immobile element ratio diagrams (Fig. 17) following Winchester and Floyd (1977); the rocks exhibit a predominantly sub-calc-alkaline to calc-alkaline character. 
Zeolite-bearing amygdaloidal volcanic and volcanoclastic rocks

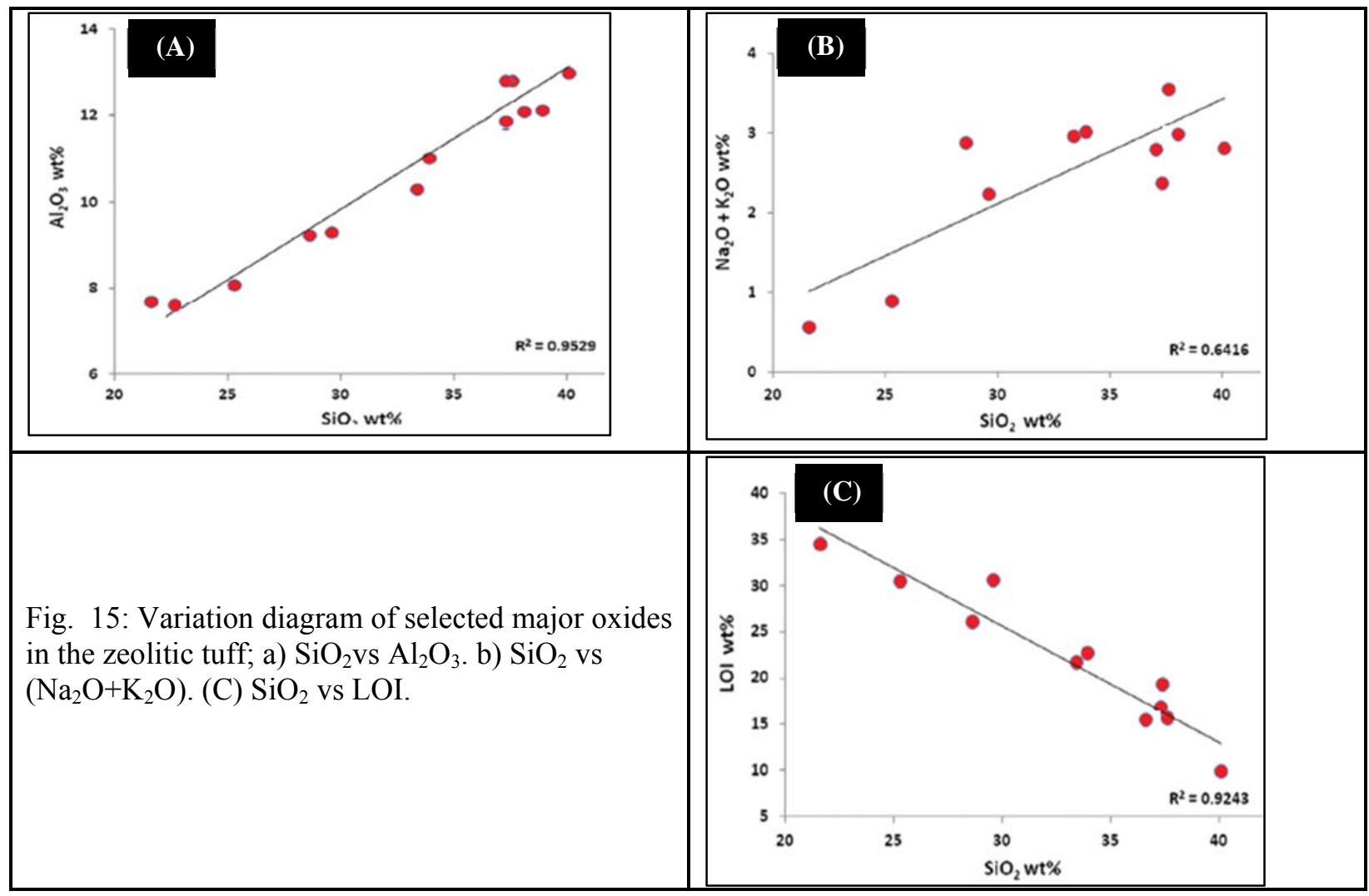

The chemical analyses of major-element oxides generally indicate that $\mathrm{Fe}, \mathrm{Ca}, \mathrm{Na}, \mathrm{Ti}, \mathrm{Mn}$, and $\mathrm{Cr}$ have been removed; and $\mathrm{Mg}, \mathrm{K}, \mathrm{Al}$, and $\mathrm{Si}$ remain practically unchanged in the zeolite-rich and vitric tuffs. The $\mathrm{SiO}_{2}, \mathrm{Al}_{2} \mathrm{O}_{3}$, and $\mathrm{Fe}_{2} \mathrm{O}_{3}$ contents of the dacite parent rock lie within the expected limits for this type of rock (Middlemost, 1985).
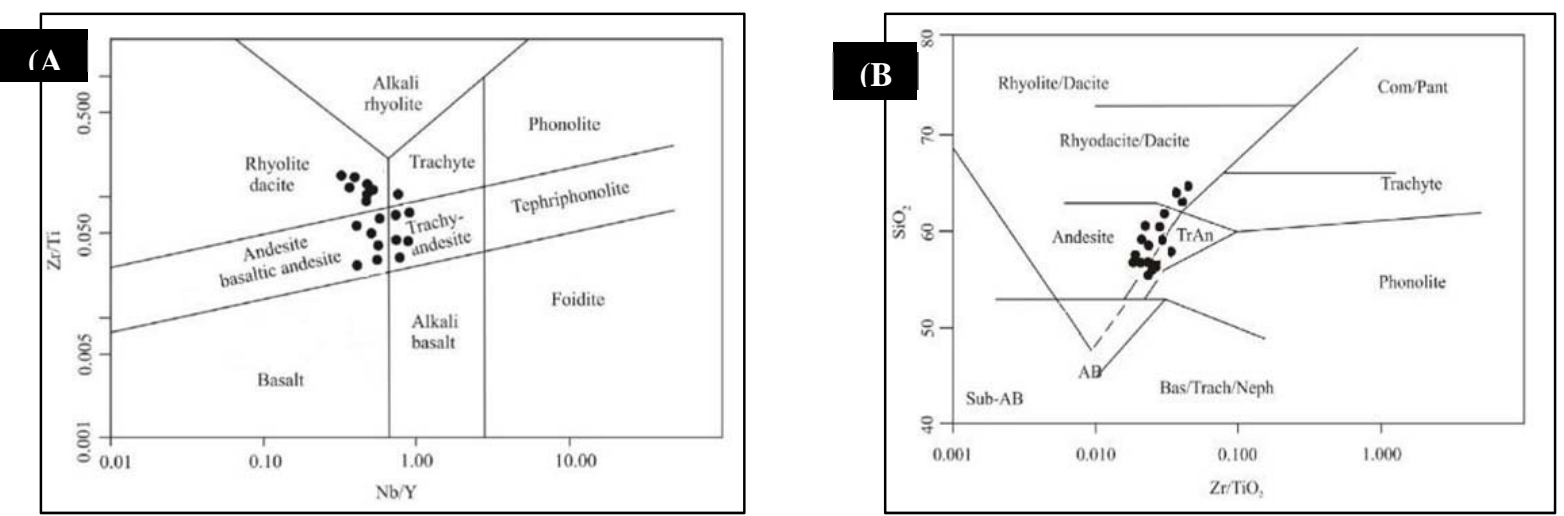

Fig. 16. (A) $\mathrm{Nb} / \mathrm{Y}$ vs. $\mathrm{Zr} / \mathrm{Ti}$ chemical classification plot for zeolitic tufts for fresh volcanic rocks after Pearce, 1996. (B) $\mathrm{Zr} / \mathrm{TiO}_{2}$ vs $\mathrm{SiO}_{2}$ bivariate plot of zeolitic tufts for volcanic rocks (after Winchester and Floyd, 1997).

The rocks of investegated area were under complex effects of fractional crystallization and continental crust assimilation. When normalized to Primitive mantle (after Sun and McDonough, 1989), the distribution patterns of rare elements in the sample groups are broadly similar, except the independent-type elements. The multi- elements spider diagrams (Fig. 17A) show peculiar patterns.

General concentrations of these incompatible elements are high; the content variations of $\mathrm{Sr}, \mathrm{Ba}$, and $\mathrm{P}$ elements are very wide. The Ba variation could be due to highly heterogeneous fluid activity in the 
Imbarak, S. H. and Al-Rashed, A. R.

intrusive bodies, which is indicated by petrographic observations. The samples $\mathrm{Rb}$ is characterized by very high incompatible elements and high $\mathrm{Ba}$, showing strong influence of fluids. The major element behavior indicate that samples are under strong effect of continental crust assimilation and the latter, originated from less fractionated acidic magma.

Primitive mantle normalized spidergram of major-element oxides for pyroclastics and tuffs (Sun and Mc-Donough, 1989); show that most samples were slightly enriched in $\mathrm{Hf}, \mathrm{Ta}, \mathrm{Sr}, \mathrm{Y}$, and $\mathrm{Nb}$ relative to the other zeolite-rich samples, possibly because of the partial release of mostly immobile elements from the rock. The REE contents of the pyroclastic, zeolite-rich tuffs, and tuffs, were normalized to chondrites (Boynton, 1984). All of the normalized sample groups showed fairly similar REE patterns (Fig 17B), and the entire sample group was enriched in REE compared to chondrites.
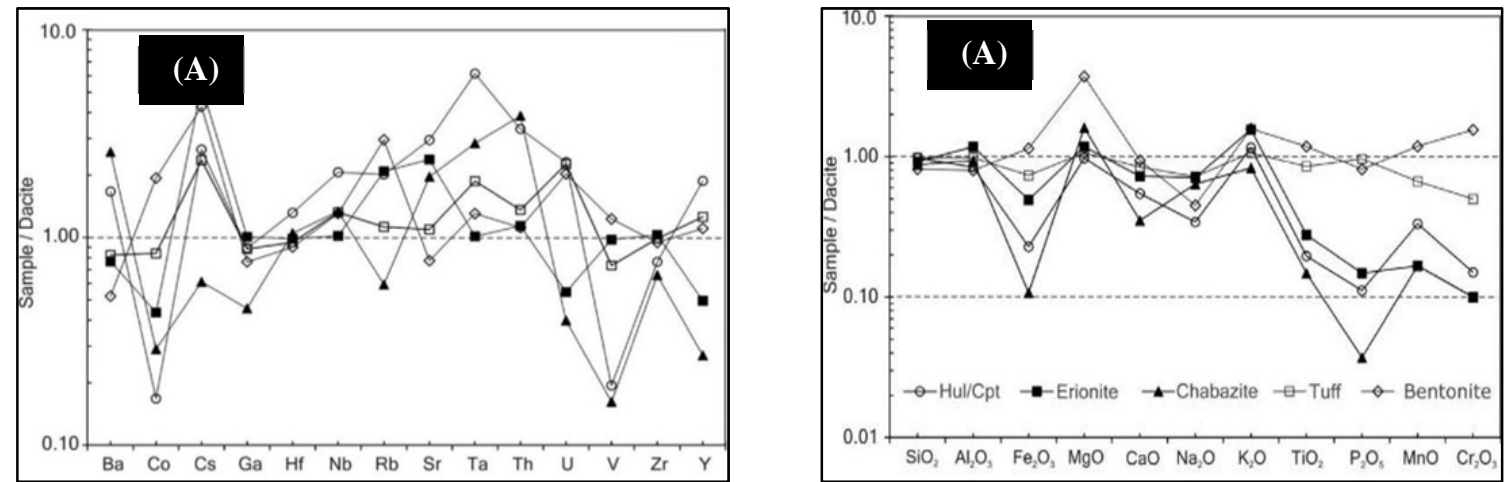

Fig. 17: (a) Primitive mantle normalized spider diagrams of major-element oxides for zeolitic tufts (after Sun and McDonough, 1989)

The normalized REE patterns of the samples were almost parallel to each other and were commonly characterized by virtually flat patterns. Eu anomalies were notable in most sample groups (Fig. 18). The LREE of the examined samples showed similar trends while their HREE are different. Some chondrite-normalized LREE are enriched relative to HREE and showed virtually concave patterns in tuffs. HREE patterns of the other sample groups are almost flat.

The tuffs contain abundant tabular clinoptilolite and chabazite crystals that formed by the replacement of the vitric fragments.

Generally, chabazite is found together with calcite and crystallized in pyroclastics that include remnant leucite forms. Phillipsite is always found as a thin rim inside the vesicles.

The studied samples show a remarkable homogeneity in their mineralogical and chemical composition. They are characterized by low $\mathrm{SiO}_{2}$ content with a very wide range of variation.

Fig. 18: Chondrite-normalized REE patterns of the investigated sample (normalization values from Boynton, 1984).

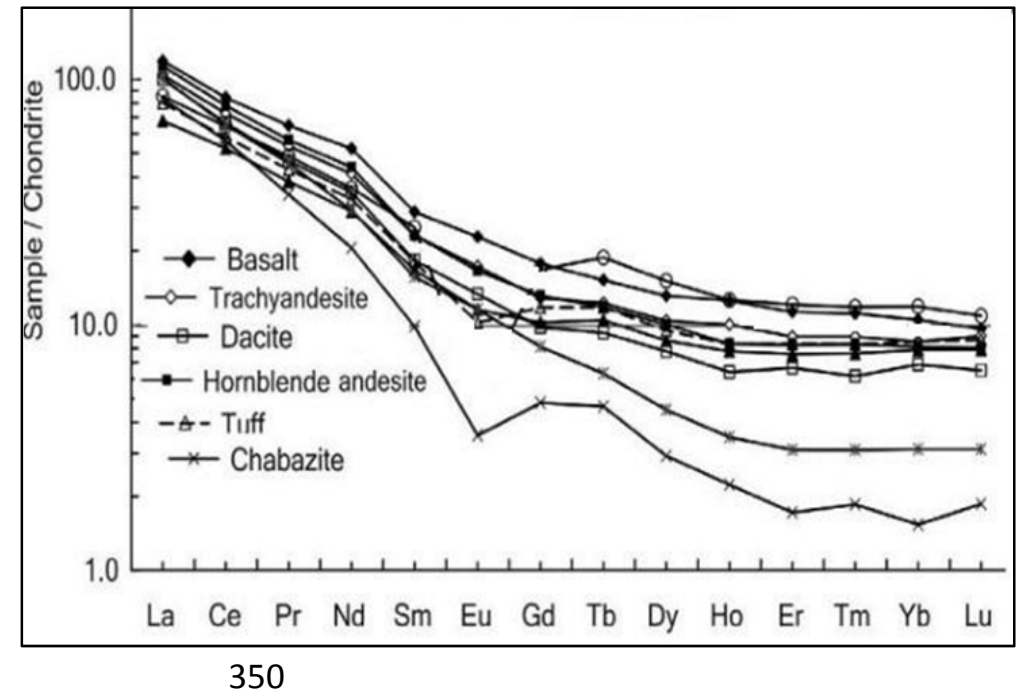


Zeolite-bearing amygdaloidal volcanic and volcanoclastic rocks

\section{SUMMARY AND CONCLUSIONS}

The Gabal Katherina complex in the high mountains of southern Sinai is composed mainly of epiclastic, volcanic, and granitoid rocks of the Precambrian Arabian-Nubian Shield. Later emplaced high-level intrusions of the Katherina ring dyke porphyries and the calc-alkaline to slightly alkaline granites of the Katherina pluton intrude into a country-rock made up mainly of metamorphic rocks, diorites, older granitoid, and inter-bedded epiclastic and volcanic rocks, which include intermediate pyroclastics with subordinate amygdules lava flows and volcanic breccias.

The occurrence of different zeolites and other secondary minerals is not homogeneous and their spatial distribution is directly controlled by host rock chemical composition and local hydrothermal conditions.

Vitrophyric and partially porphyritic textures were identified in the ignimbrite and lava samples. The volcanic rocks are characterized by amygdule and chloritized sandy appearance due to hydrothermal alteration. Zeolites fill cavities in a non-uniform way - lining cavities or filling them completely.

The amygdules minerals consist of quartz, calcite, and three calcium zeolites- laumontite, heulandite, and chabazite. Laumontite and heulandite typically coexist with quartz.

Most zeolites are relatively coarse-grained and easily identifiable. However, they sometimes occur as fine-grained aggregates, which are very difficult to identify.

Zeolite minerals usually occur as microcrystalline aggregates. They contain variable amounts of phillipsite crystals and palagonite clasts. Chabazite, smectite, calcite, were most common. Zeolites also occur in fibrous aggregates, partly or completely filling spheroid, ellipsoidal or irregular amygdales

The zeolite-rich tuffs plot near the boundary between the basaltic andesite and rhyodacite-dacite fields. The rocks exhibit a predominantly sub-calc-alkaline to calc- alkaline character

Mineral identification indicates that there are two groups of minerals: zeolitic and non-zeolitic. The zeolitic species, include analcime, is the dominant zeolitic phase, followed by chabazite, natrolite, thomsonite and stilbite.

Scanning Electron Microscopy (SEM) was used to examine the volcanic amygdule and ash, and determine the zeolitic varieties and their contents (e.g. analcime, phillipsite, clinoptilolite, thomsonite and chabazite) in volcanic rocks. The volcanic ash shows evidence of angular glassy shards. Zeolites, which are developed in pores and fractures, form crystals of regular geometric shapes including tabular, prismatic, and fibrous.

\section{REFERENCES}

Abdel Maksoud M. A., Abdel Khalek M. L. and Oweiss K. A. (1993): Geological setting of the St. Katherine Basement Rocks, Sinai, Egypt. Qatar Univ. Sci. J.13, 2, 308-318.

Be"eri-Shlevin, Y., Samuel,, M. D. Azer M. K. Rämö, O. T., Whitehouse, M. J. Moussa, H. E (2011): The EdiacaranFerani and Rutig volcano-sedimentary successions of the northernmost Arabian-Nubian Shield (ANS): New insights from zircon U-Pb geochronology, geochemistry and O-Nd isotope ratios. Precamb. Res., 188, 21-44

Boynton, W. V. (1984): Geochemistry of rare earth elements: meteorite studies. p. 63114 in: Rare Earth Element Geochemistry (P. Henderson, editor). Elsevier, Amsterdam

Deer, W. A., Howie R. A., and Zussman, J. (2004): Rock-Forming Minerals. 4B. Framework Silicates: Silica Minerals. Feldspathoids and the Zeolites, London, Bath: Geological Society of London, $982 \mathrm{pp}$.

Dyer, A. and Singh, A. P. (1988): Effect of cation exchange on heat of sorption and catalytic activity of mordenties. Zeolites, 8, 3, 242-246

El-Masry, N. N. (1991): Geological studies of palaeovolcanics and volcanoclastics of Saint Catherine Mountain area, South Sinai. M. Sc. Thesis, Suez Canal Univ., Egypt.128 pp. 


\section{Imbarak, S. H. and Al-Rashed, A. R.}

El Masry N. N., El-Kaliouby, B. A., Khawasik, S. M. and El-Ghawaby, M. A. (1992): Reconsideration of the geologic evolution of Saint Catherine ring dyke, south Sinai, Proc. $3^{\text {rd }}$ Geol. Sinai Develop, Ismailia, 229-238.

El-Masry, N. N., Hegazi, A. M., (2005): Finite strain analyses of conglomerates, Saint Catherine area, south Sinai, Egypt. Ann. Geol. Surv. Egypt, XXVIII (2005), 181- 194

El Morsy, M. M. E. (1988): Geology, Petrology and geochemistry of St. Katherine mountains, southern Sinai, Egypt. M. Sc. Thesis, Kuwait Univ., Kuwait, 170 pp.

El-Nahal, M. A., and Whittig, L. D. (1973): Cation exchange behavior of a zeoliticsodic soil. Soil Sci. Soc. Am. Proc. 37:956-958

Eyal, M. and Hezkiyahu, T. (1980): Katherina pluton; the outline of a petrological framework, Israel J. of Earth Sci., 29, 41-52.

Eyal M., Zanvilevich A. N., Litvinovsky, B. A., Jahn, B. M., Vapnik, Ye., and Beeri- Shlevin, Y. (2014): The Katherina ring complex (Sinai Peninsula, Egypt):Sequence of emplacement and petrogenesis. Am. J. Sci, 314, 462-507

Frankart, R. and Herbillon, A. J. (1970): Presence etgenèsed'analcimedans les sols sodiques de la BasseRuzizi (Burundi). Bull. Groupe Franc. Argues, 22, 79-89.

Hassen, I. S. (1997): Mineralogy, petrology and geochemistry of granitoid rocks of St. Katherine area, South Sinai, Egypt. Ph. D. Thesis (Unpublished), EötvösLorand University, Budapest, Hungary, $183 \mathrm{pp}$.

Hassen, I. S. and Al-Rashed A. R. (2017): Mineralogical, morphological characterization of soils derived from volcanic rocks of Wadi Al-Saq, Gabal Katherine area, southern Sinai, Egypt. Egypt. J. Geol., 61, 2017, 393-404.

Hawkins, D. B. (1984): Occurrence and availability of natural zeolites, in Pond, W.G., and Mumpton, F. A. (Eds.), Zeo-agriculture: Use of natural zeolites in agriculture and aquaculture, Westview Press, Boulder, Colorado, 69-78.

Hay, R. L. (1978): Geologic occurrence of zeolites, Mumpton, F.A. (ed.) Mineralogy and geology of natural zeolites. Reviews in Mineralogy, Mineral. Soc. Am 135-143.

Katzir, Y., Eyal, M., Litvinovsky, B. A., Jahn, B. M., Zanvilevich, A. N., Valley, J. W., Beeri, Y., Pelly, I., and Shimshilashvili, E., 2007, Petrogenesis of A-type granites and origin of vertical zoning in the Katherina pluton, Gebel Mussa (Mt. Moses) area, Sinai, Egypt: Lithos, 95, 3- 4, 208 -228,

Middlemost, E. A. K (1985): Magmas and Magmatic Rocks. An Introduction to Igneous Petrology, London, New York: Longman, 266 pp.

Mumpton, F. A. (1977): Utilization Natural zeolites. In: F. A. Mumpton (Ed). Mineralogy and geology of natural zeolites. Short course notes. Mineral. Soc. of Am, 4, 177-204.

Passaglia, E. and Sheppard, R. A. (2001): The crystal chemistry of zeolites. - In: BISH,

D. L. and MING, D. W. (eds.): Natural zeolites: occurrence, properties, applications. - Rev. in Mineral. and Geo. 45: $69-116$

Pearce, J. A., (1996): Sources and settings of granitic rocks. Episodes 19, 120-125.

Southard, A. R., and P. T. Kolesar. (1978): An exotic source of extractable potassium in some soils of northern Utah. Soil Sci. Soc. Am. J. 42,528-530.

Sun, S. S. and McDonough, W. F. (1989): Chemical and Isotopic Systematics of Oceanic Basalts: Implications for Mantle Composition and Processes. In: Saunders, A.D. and Norry, M.J., Eds., Magmatism in the Ocean Basins, Spec. Publ., Geol. Soc., London, 42, 313-345.

Winchester, J. A. and Floyd, P. A. (1977): Geochemical discrimination of different magma series and their differentiation products using immobile elements. Chem. Geol., 20: 325-343. 
Zeolite-bearing amygdaloidal volcanic and volcanoclastic rocks

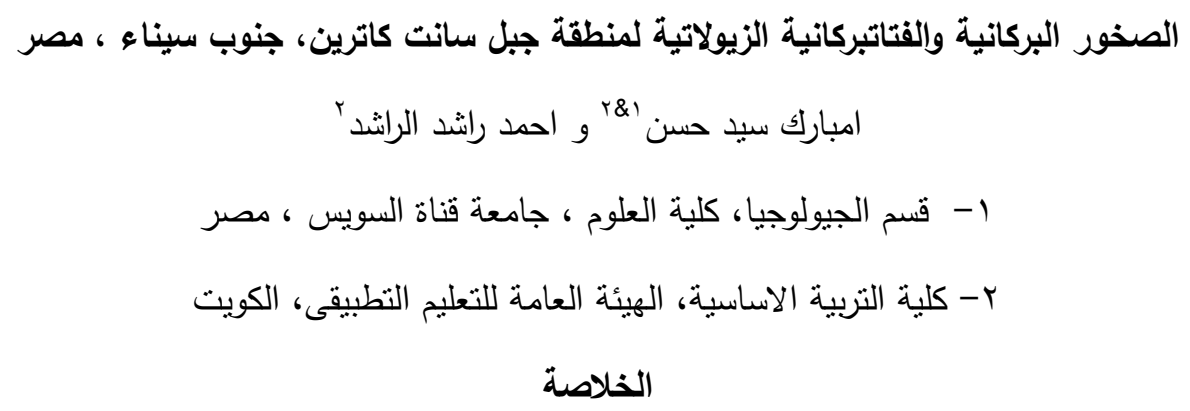

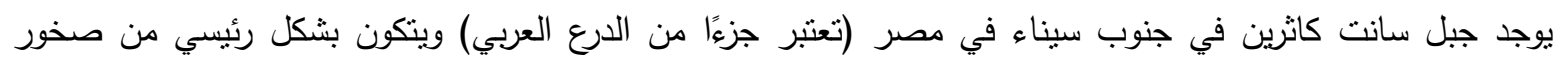

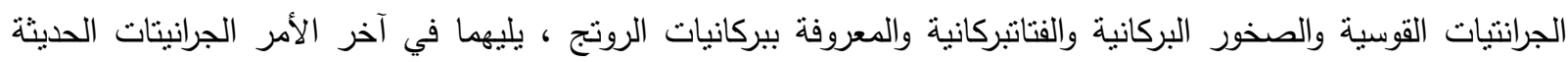

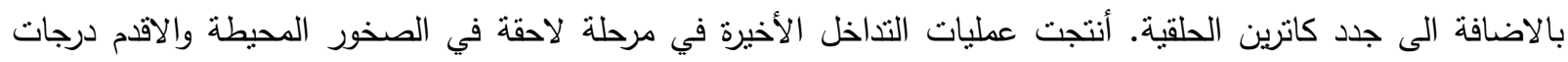

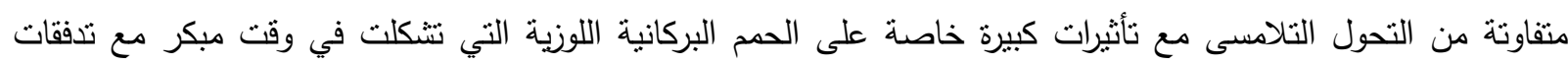

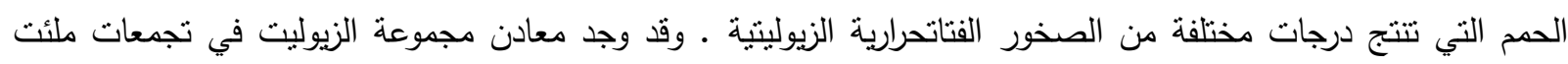
الفراغات اللوزية ذات الاثشال المختلفة بشكل جزئي أو كلي. تم فحص عينات من الفناتيات البركانية و معادن الزيوليت باستخدام المجهر البصري ، والمجهر الإكتروني الماسح

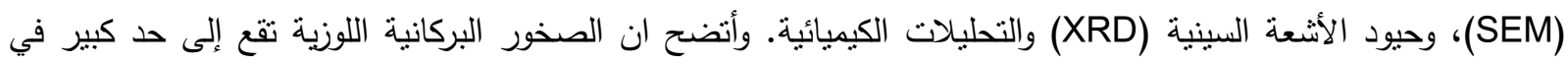

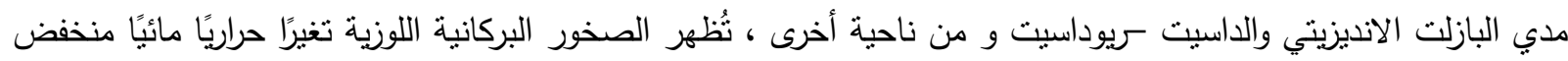

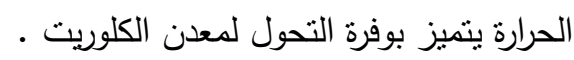
جيوكيميائيا ؛ تظهر عناصر الهافنيوم والنتنالوم والاسترنثيوم والارتريوم والنايوبيم بهذه الصخور إثراءُ طفيفًا مقارنةً بالعينات

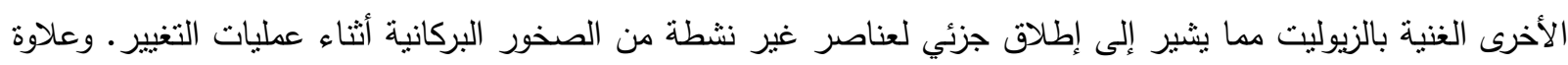

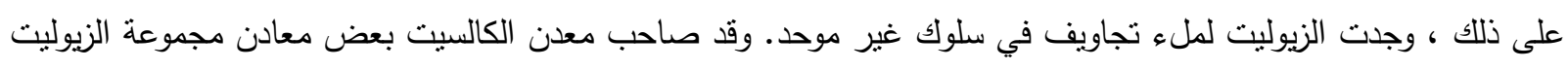

